\title{
ANALISIS PELATIHAN, PEMBERDAYAAN DAN KEPUASAN KERJA PEGAWAI DI PT BANK RAKYAT INDONESIA KANTOR CABANG KUNIINGAN
}

\author{
Wulan Dewani Putri \\ Universitas Pendidikan Indonesia \\ wulandewaniputri@student.upi.edu \\ B Lena Nuryanti \\ Universitas Pendidikan Indonesia \\ lenanuryanti@upi.edu \\ Masharyono \\ Universitas Pendidikan Indonesia \\ masharyono@upi.edu
}

\begin{abstract}
ABSTRAK
Tujuan - Tujuan penelitian ini adalah untuk menganalisis pelatihan, pemberdayaan dan kepuasan kerja.

Desain/metodologi/pendekatan - Desain penelitian ini adalah cross sectional. Penelitian ini menggunakan pendekatan deskriptif dengan metode explanatory survei. Unit analisis karyawan sebanyak 50 orang. Pengumpulan data dengan menggunakan kuesioner. Teknik analisis yang digunakan adalah teknik deskriptif dengan menggunakan distribusi frekuensi.

Temuan - Berdasarkan hasil penelitian menggunakan analisis deskriptif, didapatkan hasil bahwa pelatihan berkategori baik, pemberdayaan berkategori baik, dan kepuasan kerja berkategori tinggi.

Orisinalitas - Penelitian ini memberikan dasar untuk memahami isu-isu pelatihan dan pemberdayaan terhadap kepuasan kerja. Perbedaan penelitian ini dengan penelitian sebelumnya adalah pada objek di PT. Bank Rakyat Indonesia Kantor Cabang Kuningan, variabel pelatihan, pemberdayaan dan kepuasan kerja, serta referensi yang digunakan oleh peneliti dengan peneliti sebelumnya.

Kata kunci : : Pelatihan, Pemberdayaan, Kepuasan Kerja

Tipe artikel : Penelitian
\end{abstract}

\begin{abstract}
Purpose - The purpose of this study is to analyze empowerment training and job satisfaction.

The design / methodology / approach - The design of this study was cross sectional. This research uses descriptive approach with explanatory survey method. The employee analysis unit is 50 people. Data collection using questionnaire. The analysis technique used is descriptive technique by using frequency distribution

Findings - Based on the results of research using descriptive analysis, the results obtained that training in the good category, empowerment in the good category, and job satisfaction in the high category.

Originality - This study provides a basis for understanding the issues of the training and empowerment on job satisfaction. The difference of this research with previous research is on the object in PT. Bank Rakyat Indonesia Kuningan branch office, training variable, empowerment and job satisfaction, and references used by researchers with previous researchers.
\end{abstract}

Keywords: Training, Empowerment, Job Satisfaction Type of article: Research

\section{PENDAHULUAN}

Manajemen sumber daya manusia memperhatikan semua aspek bagaimana sumber daya bekerja dan dikelola dalam organisasi, pentingnya sumber daya manusia yaitu untuk mengkaji kapasitas dan kontribusinya sendiri terhadap organisasi (Vi, 2017) Manajemen sumber daya manusia dianggap sebagai komponen penting untuk menciptakan sumber daya yang berharga dan juga mampu mempertahankan keunggulan kompetitif organisasi (Al Adresi \& Darun, 2017). Manajemen sumber daya manusia merupakan 
kunci dalam mengubah keunggulan kompetitif menjadi keunggulan kompetitif yang berkelanjutan dengan mempengaruhi cara kerja karyawannya (Delery \& Roumpi, 2017),

Sumber daya manusia adalah aset penting atau paling kompetitif dari setiap organisasi (Batarliene, Čižiuniene, et al, 2017). Keberhasilan dan keefektifan suatu organisasi bergantung pada seberapa jauh upaya karyawan dari organisasi tersebut diakui oleh perusahaan (Eliphas, 2017), karena karyawan juga merupakan salah satu faktor yang dapat menentukan keberhasilan perusahaan (Lena, 2016), selain itu kepuasan kerja karyawan juga dapat berkontribusi untuk keberhasilan organisasi di dalam perusahaan (Maimako \& Bambale, 2016).

Kepuasan kerja masih menjadi perhatian utama dalam penelitian di bidang manajemen sumber daya manusia, karena kepuasan kerja merupakan hal penting untuk efektivitas organisasi (Arulrajah A, 2017). Setiap organisasi membutuhkan sumber daya manusia yang dapat bekerja secara efektif dan efisien (Masharyono, 2016), organisasi akan lebih efektif apabila memiliki karyawan yang merasa lebih puas dengan pekerjaannya daripada organisasi dengan karyawan yang merasa kurang puas dengan pekerjaannya (Zafeiti \& Noor, 2017).

Kepuasan kerja mengacu pada sikap umum seseorang karyawan terhadap pekerjaannya (Lena, 2016), karyawan yang puas dengan pekerjaannya merupakan hal penting dalam keberhasilan suatu perusahaan karena menjaga karyawan untuk tetap puas dengan karirnya harus menjadi prioritas utama bagi setiap perusahaan. Outcome dari perusahaan sebagian besar tergantung pada kepuasan karyawannya (Nabi NM, Foyso KM, \& Adnan SM, 2017).

Permasalahan kepuasan kerja terjadi pada berbagai industri baik manufaktur atau industri jasa (Mahmood \& Ur Rehman, 2016). Perbankan merupakan salah satu dari Industri jasa yang mengalami masalah kepuasan kerja dalam industri perbankan tingkat kepuasan kerja karyawan antara satu bank dengan bank yang lain bisa bervariasi, hal ini disebabkan karena setiap bank menerapkan standar gaji yang berbeda, beban kerja, serta lingkungan kerja yang berbeda pula (Agbozo, Owusu, Hoedoafia, \& Atakorah, 2017). Tingkat kepuasan kerja karyawan di Indonesia pada tahun 2017 mencapai rating 2.75, angka tersebut masih rendah jika dibandingkan dengan tingkat kepuasan kerja karyawan di Negara Poland yang memperoleh rating 3.29. Industri perbankan di Indonesia memiliki tingkat kepuasan kerja cukup tinggi dengan rating 2.75 , akan tetapi kategori workload atau beban kerja di dalam industri perbankan memperoleh rating terendah 2,31, dibandingkan dengan kategori lainnya seperti job demand atau tuntutan pekerjaan yang memperoleh rating 3 (www.salaryexplorer.com diakses tanggal 03/09/2017 pukul 17.29). Data tersebut menunjukkan bahwa permasalahan kepuasan kerja karyawan masih menjadi fokus utama di dalam industri perbankan.

Permasalahan kepuasan kerja juga diperkuat dengan adanya penelitian pada industri perbankan di Indonesia. Permasalahan kepuasan kerja terjadi pada beberapa perusahaan industri perbankan di daerah Jawa Timur, Malang, Bandung dan Kalimantan Timur (Rachmat Hidayat, 2013; Jayanthi, 2014, Rama, 2017; Partono Prasetio, Yuniarsih, \& Ahman, 2017). Kualitas sumber daya manusia sangat dipengaruhi oleh kepuasan kerja karyawan, karena karyawan yang puas dan bahagia dengan pekerjaannya akan melakukan pekerjaan yang baik dan juga berkualitas (Neog, 2014; Bagus, Dharmanegara, Sitiari, \& Adelina, 2016), karyawan juga merupakan salah satu faktor yang dapat menentukan keberhasilan perusahaan (B. L. Nuryanti, 2016).

Peringkat kepuasan kerja pada industri perbankan dapat dilihat secara umum, BCA menempati posisi tertinggi menempati peringkat ke2 dengan rating kepuasan kerja karyawan yang mencapai 4,1 dan rata-rata gaji 4,34 juta/bulan, sementara bank BNI menempati peringkat ke-14 dengan rating kepuasan kerja karyawan yang mencapai 3,7 dan rata-rata gaji 4,84 juta/bulan, dan bank BRI menempati peringkat ke-18 dengan rating kepuasan karyawan BRI adalah 3,7 dan rata-rata gaji 3,74 juta/bulan (www.jobplanet.com diakses tanggal 18/09/2017 pukul 15.43). Bila dibandingkan dengan bank BCA dan BNI kepuasan kerja karyawan terendah ditempati oleh PT. Bank Rakyat Indonesia.

Persaingan antar perusahaan bukanlah persaingan antar mesin ataupun antara bangunan, tapi perusahaan yang memiliki karyawan yang lebih baik adalah perusahaan yang akan memenangkan persaingan (Masharyono, 2016). Keinginan karyawan untuk meninggalkan sebuah organisasi dan mencari pekerjaan lain, adalah evaluasi yang berkenan dengan ketidakpuasan kerja (Maulana \& Anindita, 2017).

Kepuasan kerja memiliki dampak pada kehidupan umum karyawan juga karena karyawan yang puas adalah manusia yang puas dan bahagia (Waqas et al., 2014), efektivitas dalam organisasi akan meningkat ketika karyawan merasa puas, karena karyawan yang puas, bahagia dan pekerja 
keras adalah aset terbesar dari setiap organisasi (Jain, Ruchi, Kaur, 2014).

Penting bagi bank untuk menjaga dan meningkatkan karyawan untuk puas dengan pekerjaannya sehingga dapat mempertahankan posisinya di industri perbankan yang kompetitif ini (Raziq \& Maulabakhsh, 2015). Karyawan merupakan salah satu komponen terpenting yang dimiliki oleh perusahaan, karena upayanya menjaga kelangsungan hidup, mengembangkan, kemampuan bersaing dan menghasilkan keuntungan (Masharyono, 2017).

Permasalahan kepuasan kerja jika diabaikan akan meningkatkan jumlah karyawan yang berhenti (Zhang, 2016). Mengingat permasalahan kepuasan kerja sangat penting untuk perusahaan, maka masalah tersebut dapat diatasi dengan pendekatan Manajemen Sumber Daya Manusia yang merupakan salah satu bidang dari manajemen umum yang meliputi segi-segi perencanaan, pengorganisasi, pelaksanaan dan pengendalian (Veithzal \& Ella Jauvani, 2014). Menurut teori Herzberg's terdapat two factors theory dalam kepuasan kerja, yaitu motivation dan hygiene. Karyawan yang puas dimotivasi dari dalam untuk bekerja lebih keras. Dua faktor herzberg adalah pemuas dan pembeda. Ketidakpuasan dikaitkan dengan keluhan tentang konteks atau fakta di lingkungan kerja secara langsung (Vallabhaneni, 2017).

Terdapat beberapa penelitian tentang faktorfaktor yang mempengaruhi kepuasan kerja diantaranya ialah gaji/upah (pay), promosi (promotion), lingkungan kerja (work environment), semangat tim (team spirit), keamanan kerja (job security), citra perusahaan (corporate image), kepiawaian pengawas (supervisor's expertise), kerja sama (collaborative), pengembangan profesi (professional development), rotasi kerja (job rotation), komunikasi efektif (communication effectiveness), kepemimpinan (leadership), motivasi (motivation), pelatihan (training) dan pemberdayaan (empowerment) (Chien, 2015; Tran \& Thao, 2015; Uddin, Chowdhury, \& Yasmin, 2016). Berdasarkan faktor-faktor tersebut, yang dilakukan maka diambil beberapa solusi untuk meningkatkan kepuasan kerja karyawan yaitu dengan pelatihan, dan pemberdayaan.

Solusi pertama yaitu pelatihan, pelatihan merupakan proses yang sistematis untuk mengubah perilaku, pengetahuan, dan motivasi karyawan (Olagunju, 2014). Pelatihan sebagai upaya terencana oleh perusahaan untuk memudahkan karyawan dalam mempelajari keterampilan kerja, dan keterampilan ini mencakup pengetahuan, keterampilan, atau perilaku yang sangat penting bagi keberhasilan kinerja (Zu'bi \& Alkharabsheh, 2016). Penelitian yang dilakukan oleh Osama, Haseeb, Waseem, Ayaz mengatakan bahwa pelatihan berpengaruh terhadap kepuasan kerja, sedangkan penelitian yang dilakukan oleh Johnson \& Umoh pelatihan tidak berpengaruh terhadap kepuasan kerja. (Osama, Haseeb, Waseem, Ayaz, \& Ijaz, 2016; Johnson \& Umoh, 2016)

Solusi kedua yaitu pemberdayaan, pemberdayaan merupakan proses yang menyediakan otonomi yang lebih besar melalui berbagi informasi yang relevan dan penyediaan kontrol atas faktor yang mempengaruhi prestasi kerja (Risher \& Wilder, 2016). Dengan kata lain, pemberdayaan adalah suatu tindakan atau upaya untuk meningkatkan daya karyawan dalam hal otoritas, otonomi, peran, dan pengaruh dalam organisasi. Karyawan diberdayakan secara independen dapat menetapkan tujuan mereka sendiri, mengambil keputusan yang berkaitan dengan pekerjaan mereka, melaksanakan keputusan, dan memecahkan masalah. Pemberdayaan karyawan berarti memberi karyawan tanggung jawab dan wewenang untuk membuat keputusan tentang semua aspek pengembangan produk atau layanan pelanggan. Pemberdayaan dianggap mampu menumbuhkan dan meningkatkan kreativitas karyawan (Indah, 2017). Penelitian yang dilakukan oleh Tetik menyatakan bahwa pemberdayaan karyawan memiliki pengaruh positif dan signifikan terhadap kepuasan kerja, sedangkan penelitian yang dilakukan oleh Ampauleng mengatakan bahwa pemberdayaan tidak berpengaruh terhadap kepuasan kerja (Tetik, 2016; Ampauleng, 2016).

Berdasarkan latar belakang masalah di atas, maka tujuan penelitian ini adalah untuk memperoleh hasil temuan mengenai: (1) memperoleh temuan gambaran pelatihan, (2) memperoleh temuan gambaran pemberdayaan, (3) memperoleh temuan gambaran kepuasan kerja

\section{KAJIAN PUSTAKA}

Manajemen sumber daya manusia sangat penting untuk keberhasilan organisasi seperti halnya potensi manusia yang memiliki kualitas tertentu yang membuatnya berharga Noe et al. (2016). Manajemen sumber daya manusia adalah fungsi organisasi yang bertanggung jawab untuk menarik, mempekerjakan, mengembangkan, memberi penghargaan dan mempertahankan keterampilan karyawan. (Jean M. Phillips, 2013). 
Manajemen sumber daya manusia dimulai dengan definisi jumlah orang yang dibutuhkan, yang memiliki keterampilan tertentu untuk melaksanakan tugas tertentu. Setelah itu, calon karyawan harus ditemukan, direkrut, dan dipilih. Setelah merekrut, karyawan harus dilatih atau dilatih ulang, dinasihati, dievaluasi, diarahkan, dihargai, ditransfer, dipromosikan, dan akhirnya terlepas atau pensiun (Marta, 2014:9).

Manajemen sumber daya manusia adalah suatu ilmu atau cara bagaimana mengatur hubungan dan peranan sumber daya (tenaga kerja) yang dimiliki oleh individu secara efektif dan efisien serta dapat digunakan secara maksimal, sumber keunggulan kompetitif yang efektif dapat meningkatkan kinerja perusahaan secara signifikan sehingga tercapai tujuan bersama, (M. Ronald Buckley, Anthony R. Wheeler, 2017)

Noe et al. (2016) mengemukakan terdapat sembilan fungsi dari manajemen sumber daya manusia yaitu 1) analysis and design of work, 2) recruitment and selection, 3) training and development, 4) performance management, 5) compensation and benefits, 6) employee relations, 7) personnel policies, 8) employee data and information systems, 9) compliance with laws, 10) support for strategy.

. Berdasarkan pada fungsi sumber daya manusia tersebut terdapat fungsi training and development yang merupakan upaya untuk meningkatkan kemampuan karyawan untuk menangani berbagai tugas dan untuk menumbuhkan kemampuan karyawan di luar yang yang dibutuhkan oleh pekerjaan saat ini yang dapat menguntukan kedua belah pihak, baik individu maupun organisasi (Ina Ehnert, Wes Harry, 2013:120).

Pelatihan termasuk kedalam fungsi training and development, pelatihan dapat menciptakan nilai dalam setiap aspek dari sistem manajemen sumber daya manusia. Pelatihan dirancang untuk memberikan individu pengalaman yang luas melalui pengetahuan dan keterampilan dan sikap (Lesley Walls, Matthew Revie, 2017:991).

Pelatihan adalah kunci untuk pembelajaran dan pertumbuhan (Keyes, 2016). Pelatihan cenderung untuk menunjukkan pembelajaran dengan instruksi, misalnya, melalui demonstrasi, praktek dipandu atau pembinaan, dalam keterampilan atau praktik tertentu. Pelatihan ini dimaksudkan untuk menghasilkan perubahan perilaku di tempat kerja menyebabkan peningkatan kinerja individu untuk memenuhi kebutuhan organisasi pada titik waktu tertentu (Wilton, 2016).

Pelatihan adalah upaya terencana organisasi untuk membantu karyawan memperoleh pengetahuan, keterampilan, kemampuan, dan perilaku terkait pekerjaan, dengan tujuan menerapkannya pada pekerjaan (Noe et al, 2016). Pelatihan berorientasi ke masa sekarang membantu karyawan untuk menguasai keterampilan dalam pekerjaannya (Sutrisno, 2017). Selama pelatihan, semua peserta harus mendapat perlakuan yang sama, seperti kesempatan berlatih yang setara. Program pelatihan yang efektif benar-benar harus mengajarkan apa yang dirancang dan diajarkan kepada karyawan, untuk meningkatkan keterampilan dan kemampuan mereka, demi kepentingan individu dan organisasi (Charles Leatherbarrow, 2014).

Karakteristik pelatihan menurut $M$. Ronald Buckley, Anthony R. Wheeler (2017) beberapa jenis pelatihan seperti pelatihan ketrampilan interpersonal dan pelatihan keterampilan komunikasi secara langsung membahas aspek emosional kerja. khususnya, baik peserta pelatihan dan pelatih sering ditantang untuk menilai kembali keterampilan dan kemampuan karyawan sendiri. Dimensi pelatihan menurut menurut $\mathrm{Noe}$ et al (2016:201), yaitu 1) knowledge (pengetahuan), 2) skills (keterampilan), 3) abilities (kemampuan), 4) behaviors (perilaku).

Menurut Noe et al., (2016) peran pelatihan bagi karyawan yaitu untuk memperoleh pengetahuan dan keterampilan, program pelatihan harus dilaksanakan dengan cara yang sesuai dengan kebutuhan dari karyawannya. Karyawan yang telah mengikuti pelatihan harus memiliki perubahan yang lebih baik dalam bekerja. Penerapan program pelatihan harus memungkinkan karyawan mentransfer apa yang telah dipelajari ke tempat karyawan itu berkeja, karyawan didorong untuk berbagi pengetahuan dengan rekan kerjanya.

Berdasarkan pada fungsi sumber daya manusia terdapat fungsi support for strategy yang berhubungan dengan pemberdayaan. Fungsi support for strategy menempatkan keberhasilan perusahaan yaitu untuk dapat memanfaatkan sumber daya manusia agar bersedia bekerja dengan sungguh-sungguh berpartisipasi dalam mencapai tujuan organisasi/perusahaan dan memperhatikan kebutuhan karyawan. Pemberdayaan sebagai menciptakan kondisi untuk motivasi tinggi melalui pengembangan rasa yang kuat self efficacy pribadi, ini berarti berbagi kekuasaan sedemikian rupa bahwa individu belajar untuk percaya pada kemampuan mereka untuk melakukan pekerjaan (Nelson \& Quick, 2012:189). Adanya pemberdayaan karyawan juga menolong karyawan untuk merasa bahwa kontribusi mereka mempunyai arti, bahwa mereka berkompeten dan mereka 
mempunyai pilihan terhadap apa yang dikerjakannya.

Pemberdayaan adalah memberikan kekuasaan. Pemberdayaan berarti memberikan karyawan sarana, kemampuan dan kewenangan untuk memungkinkan karyawan untuk melakukan beberapa pekerjaan. Pemberdayaan adalah proses yang menyediakan otonomi yang lebih besar melalui berbagi informasi yang relevan dan penyediaan kontrol atas faktor yang mempengaruhi prestasi kerja (Khanka, 2007)

Pemberdayaan didasarkan pada keyakinan bahwa karyawan perlu organisasi sebanyak kebutuhan organisasi membutuhkan karyawan, dan bahwa para pemimpin memahami bahwa karyawan adalah aset yang paling berharga dalam perusahaan (Michael, 2009).

Pemberdayaan adalah memberi tanggung jawab dan wewenang kepada karyawan untuk membuat keputusan mengenai semua aspek pengembangan produk atau layanan pelanggan (Noe et al., 2016:38) dapat dikatakan pemberdayaan adalah memberikan karyawan sarana, kemampuan dan kewenangan untuk memungkinkan karyawan untuk bertanggung jawab melakukan beberapa pekerjaan. Karyawan diberdayakan secara independen dapat menetapkan tujuan mereka sendiri, mengambil keputusan yang berkaitan dengan pekerjaan mereka, melaksanakan keputusan, dan memecahkan masalah. Para pemimpin memahami bahwa karyawan adalah aset yang paling berharga dalam perusahaan.

Fungsi dari pemberdayaan menurut Noe et al., 2016) yaitu karyawan bertanggung jawab dan mendapatkan wewenang mengenai semua aspek pengembangan produk atau layanan pelanggan, karyawan kemudian dapat bertanggung jawab atas produk dan layanan yang telah diberikan. Memberdayakan karyawan adalah merancang pekerjaan, karyawan mempertemukan berbagai keterampilan dan pengalaman. Proses pemberdayaan berfungsi melalui proyek dan program, membangun kapasitas dan transformasi hubungan.

Karakteristik pemberdayaan menurut Noe et al., (2016), yaitu memberi tanggung jawab dan wewenang kepada karyawan untuk membuat keputusan mengenai semua aspek pengembangan produk atau layanan. Organisasi tersebut meminta pertanggungjawaban karyawan terhadap produk dan layanan. Pemberdayaan karyawan juga mendapatkan umpan balik dan penghargaan yang sesuai untuk pekerjaan karyawan yang diberdayakan.
Peran pemberdayaan menurut Noe et al., (2016) pemberdayaan karyawan berarti memberi tanggung jawab dan wewenang kepada karyawan untuk membuat keputusan. Peran pemberdayaan berarti bagi karyawan, karena adanya pemberdayaan, karyawan dapat berperan mengambil keputusan dan bertanggung jawab atas apa yang telah dikerjakan, yang memungkinkan karyawan untuk melakukan pekerjaan secara efektif dan efisien dengan menggunakan kreativitas, imajinasi, pengetahuan, dan keterampilan mereka.

Dimensi pemberdayaan menurut Noe et al (2016:38) yaitu responsibility (tanggung jawab), dan authority (wewenang). Responsibility berarti karyawan bertanggung jawab untuk melakukan pekerjaan yang baik dan mengembangkan keterampilan yang terus membuat mereka berharga bagi atasan mereka. Autority. Karyawan harus diberikan wewenang dalam pengambilan keputusan dalam pekerjaannya, kewenangan pengambilan keputusan antara individu, subkelompok, dan tim secara keseluruhan.

Menurut Noe et al., (2016) faktor yang mempengaruhi pemberdayaan karyawan yaitu merancang pekerjaan, sistem penilaian dan penghargaan yang tepat memiliki pengaruh dalam pemberdayaan karyawan. Merancang pekerjaan adalah proses untuk menentukan bagaimana pekerjaan akan dilakukan dan tugas apa yang akan dibutuhkan dalam pekerjaan tertentu. Sistem penilaian dan penghargaan membuat meningkatnya motivasi karyawan dalam bekerja. Karyawan akan merasa percaya diri dengan apa yang telah dikerjakan.

Sumber daya manusia akan merasa puas dalam bekerja apabila aspek pekerjaan dan individunya saling menunjang sehingga dapat dikatakan bahwa kepuasan kerja berkenaan dengan perasaan seseorang tentang menyenangkan atau tidaknya pekerjaan karyawan, kepuasan kerja melibatkan perasaan positif seseorang sehingga individu dapat mengevaluasi pekerjaan yang dikerjakannya (Tom \& Adrian, 2002:134;Mathis, Jackson, \& Valentine, 2015).

Kepuasan kerja merupakan sasaran penting dalam manajemen sumber daya manusia karena kepuasan kerja akan mempengaruhi kinerja dan produktivitas kerja (Tsounis \& Vlachvei, 2017). Sumber daya manusia seharusnya mendapat perhatian lebih dibandingkan dengan sumber daya lainnya karena manusia memiliki pikiran, perasaan yang dapat mempengaruhi keberhasilan suatu organisasi. Manajemen sumber daya manusia yaitu kebijakan dan praktik menentukan aspek manusia atau sumber daya manusia dalam posisi 
manajemen, termasuk merekrut, menyaring, melatih, memberi penghargaan, dan penilaian (Garry, 2013).

Kepuasan kerja terdiri dari keinginan karyawan untuk mendapatkan tingkat kinerja yang tinggi dan menunjukkan kesetiaan pada organisasi (Tsounis \& Vlachvei, 2016). Kepuasan atau ketidakpuasan kerja tergantung pada perbedaan antara apa yang diharapkan. Sumber daya manusia akan merasa puas dalam bekerja apabila aspek pekerjaan dan individunya saling menunjang sehingga dapat dikatakan bahwa kepuasan kerja berkenaan dengan perasaan seseorang tentang menyenangkan atau tidaknya pekerjaan karyawan, kepuasan kerja melibatkan perasaan positif seseorang sehingga individu dapat mengevaluasi pekerjaan yang dikerjakannya (Tom \& Adrian, 2002; Mathis, Jackson, \& Valentine, 2015).

Kepuasan kerja adalah perasaan emosional yang positif, hasil evaluasi seseorang terhadap pekerjaannya dan pengalaman pekerjaannya dengan membandingkan antara apa yang diharapkan dari pekerjaannya dan apa yang benar-benar didapatkannya. Kepuasan kerja juga dapat dikatakan sebagai hasil interaksi dari karyawan dan persepsi terhadap pekerjaannya dan lingkungan kerja (Locke, 1976; Anju, 2005).

Kepuasan kerja adalah keadaan emosi positif yang dihasilkan dari mengevaluasi pengalaman kerja seseorang (Robert L \& Jackson, 2010). Kepuasan kerja adalah sejauh mana seorang individu senang dengan pekerjaannya, itu terlihat sebagai persepsi seseorang memiliki hasil yang diinginkan dibandingkan dengan hasil aktual dalam konteks pekerjaan, atau sejauh mana harapan individu telah terpenuhi dari waktu ke waktu (Fields, 2002).

Kepuasan kerja adalah konsep kompleks dan beragam yang berarti mendapatkan hal yang berbeda untuk setiap individu. Kepuasan kerja tidak sama seperti motivasi, kepuasan kerja lebih dari sikap, keadaan internal terkait dengan perasaan pribadi, prestasi, baik kuantitatif maupun kualitatif (Mullins, 2005).

Kepuasan kerja pada dasarnya merupakan sesuatu yang bersifat individual. Kepuasan kerja karyawan mencerminkan perasaan seseorang terhadap pekerjaannya yang dapat terlihat dari sikap karyawan terhadap pekerjaan dan segala sesuatu di lingkungan pekerjaan (V.S.P. Rao, 2009). Kepuasan kerja dapat dilihat tidak hanya saat melakukan pekerjaan, tetapi dapat dilihat dengan aspek lain seperti interaksi dengan rekan kerja, atasan, mengikuti peraturan, dan lingkungan kerja (Alexandris, 2013).
Kepuasan kerja dapat dipengaruhi dengan nilai-nilai kerja, ketidakmampuan seseorang, imbalan kerja, etos kerja, atribut pribadi, jam kerja, emosi, kinerja, ancaman terhadap stabilitas pekerjaan, dan lingkungan kerja (Vriti, 2015:).

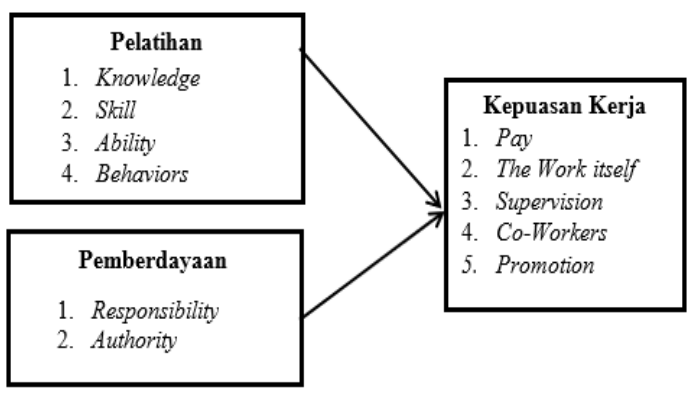

Kepuasan kerja merupakan perasaan menyenangkan yang dihasilkan dari persepsi bahwa pekerjaan yang dilakukan memenuhi nilai penting dalam pekerjaannya (Noe et al 2016:350). Menurut (Noe et al 2016:350) terdapat lima dimensi kepuasan kerja, yaitu 1) pay (gaji), 2) the work itself (pekerjaan itu sendiri), 3) supervision (pimpinan), 4) co-workers (rekan kerja), 5) promotions (promosi).

Gambar 1. Paradigma Penelitian

\section{METODE PENELITIAN}

Penelitian ini untuk menganalisis pelatihan dan pemberdayaan, dan kepuasan kerja. Variabel dalam penelitian ini yaitu pelatihan, pemberdayaan dan kepuasan kerja. Variabel pelatihan dengan dimensinya yaitu knowledge (pengetahuan), skills (keterampilan), ability (kemampuan), dan behaviors (perilaku). Serta pemberdayaan yang memiliki dimensi responsibility (tanggung jawab) dan authority (wewenang). Serta variabel terikat yaitu kepuasan kerja dimensinya mencakup pay (gaji), the work itself (pekerjaan itu sendiri), supervision (atasan), co-workers (rekan kerja), dan promotions (promosi).

Berdasarkan pada variabel-variabel yang akan diteliti maka jenis penelitian berdasarkan tujuan yang ingin dicapai yaitu jenis penelitian deskriptif. Berdasarkan jenis penelitian di atas yaitu penelitian deskriptif maka metode yang digunakan adalah explanatory survey.

\section{HASIL DAN PEMBAHASAN}


Pelatihan adalah bentuk pengalaman yang dirancang untuk melakukan lebih memadai tugasnya yang ada, kegiatan dan program yang menghasilkan karyawan mencapai tingkat pengetahuan, keterampilan, kompetensi dan kemampuan untuk melaksanakan pekerjaan mereka secara efektif untuk tujuan suatu pekerjaan atau tugas (Olagunju, 2014a). Pelatihan dirancang untuk memberikan individu pengalaman yang luas melalui pengetahuan dan keterampilan dan sikap (Lesley Walls, Matthew Revie, 2017). Dalam pelatihan terdapat 4 dimensi menurut Noe et al (2016) yaitu 1) knowledge (pengetahuan), 2) skills (keterampilan), 3) abilities (kemampuan), 4) behaviors (perilaku).

Knowledge (pengetahuan) artinya berbagi, oleh karena itu, satu tantangan yaitu adalah mengalihkan fokus pelatihan dari sekedar keterampilan mengajar dan menuju fokus yang lebih luas dalam menghasilkan dan mampu berbagi pengetahuan (Noe et al., 2016).

Skills (keterampilan) untuk membantu agar mempermudah tercapainya suatu tujuan (Noe et al., 2016). Keterampilan ini harus dapat diukur, diamati dan dapat dipandu karena memiliki dampak penting terhadap kinerja individu serta keberhasilan perusahaan (Chan, 2014).

Abilities (kemampuan) yaitu kemampuan dalam menggunakan pengetahuan, metode, teknik, dan peralatan yang diperlukan untuk melaksanakan tugas tertentu yang diperoleh dari pengalaman dalam pelatihan (Noe et al., 2016). Karyawan harus memiliki kemampuan yang sangat cocok dengan tempat kerja dan dengan organisasi, jika organisasi terus melatih mereka, karyawan ini akan tersedia untuk menjadi karyawan penting, meningkatkan daya saing dan produktivitas organisasi (Navarro, 2015).

Behaviors (perilaku) yaitu perubahan perilaku setelah pelatihan yang tercermin dalam proses kerja (Noe et al., 2016). Program pelatihan telah dirancang untuk mengubah perilaku karyawan dengan memperkuat perilaku pekerja yang diinginkan, yang dapat meningkatkan motivasi pekerja (Maitland, 2014). Pelatihan ini dimaksudkan untuk menghasilkan perubahan perilaku di tempat kerja menyebabkan peningkatan kinerja individu untuk memenuhi kebutuhan organisasi pada titik waktu tertentu (Wilton, 2016).

Berdasarkan hasil pengolahan data yang dilakukan melalui penyebaran angket pada pegawai PT. Bank Rakyat Indonesia kantor Cabang Kuningan, pelatihan dapat diukur melalui perhitungan rata-rata dimensi dan perhitungan skor keseluruhan. Berikut ini dipaparkan hasil dari rekapitulasi perhitungan skor:

TABEL 4.1 REKAPITULASI DIMENSI PELATIHAN

\begin{tabular}{llccc}
\hline No. & \multicolumn{1}{c}{ Dimensi } & $\begin{array}{l}\text { Total } \\
\text { Skor }\end{array}$ & $\begin{array}{c}\text { Skor } \\
\text { Ideal }\end{array}$ & \multirow{2}{*}{$\%$} \\
\hline Pelatihan & & & \\
\hline 1. & Knowledge (pengetahuan) & 3391 & 4200 & $81 \%$ \\
2. Skills (keterampilan) & 3391 & 4200 & $81 \%$ \\
3. Abilities (kemampuan) & 4362 & 5250 & $83 \%$ \\
4. & Behavior (perilaku) & 4263 & 5250 & $81 \%$ \\
\hline \multicolumn{2}{r}{ Total } & $\mathbf{1 5 4 0 7}$ & $\mathbf{1 8 9 0 0}$ & $\mathbf{8 2 \%}$ \\
\hline
\end{tabular}

Sumber: Hasil Pengolahan Data 2018

Berdasarkan Tabel 4.1 aspek pelatihan paling tinggi yaitu terdapat pada dimensi abilities (kemampuan) memperoleh skor sebanyak 4362 atau $83 \%$, sementara dimensi paling rendah yaitu pada knowledge (pengetahuan) dan skills (keterampilan) memperoleh skor 3391 atau $81 \%$. Secara keseluruhan variabel pelatihan memperoleh skor 15407, apabila di persentasekan kedalam skor ideal maka diperoleh persentase sebesar 82\%, dapat dikatakan menurut Moch. Ali (Ali, 2013:184) bahwa hampir seluruh responden menyatakan pelatihan pada pegawai PT. Bank Rakyat Indonesia Kantor Cabang Kuningan dalam kategori baik (Ali,

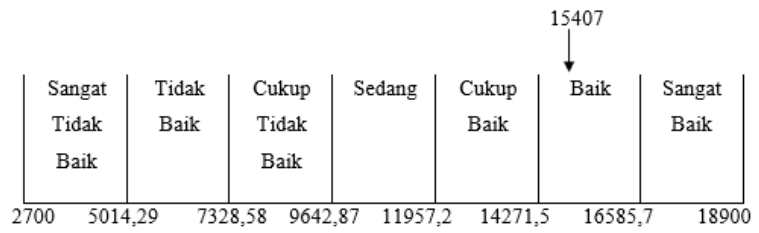

Sumber: Pengolahan Data 2018

2013). Sedangkan dilihat dari garis kontinum yang telah dihitung adalah:

\section{GAMBAR 4.1}

GARIS KONTINUM VARIABEL PELATIHAN

Berdasarkan Gambar 4.1 pada nilai kontinum variabel pelatihan yaitu 15407 sesuai dengan data penelitian yaitu termasuk kedalam kategori efektif, dengan demikian dapat dikatakan bahwa pegawai mengikuti pelatihan yang efektif dijalankan pada perusahaan, akan tetapi pelatihan pada perusahaan masih perlu ditingkatkan karena semua dimensi berada di bawah skor ideal.

Berdasarkan hasil penelitian dari angket yang disebar kepada 50 responden diketahui bahwa pelatihan pegawai PT. Bank Rakyat Indonesia kantor Cabang Kuningan mencapai skor 15407 dari skor kriterium atau jumlah maksimal perolehan nilai responden terletak pada daerah 14271,5 16585,7 sehingga dapat dikatakan bahwa dalam penelitian ini pelatihan pegawai PT. Bank Rakyat Indonesia kantor Cabang Kuningan sudah efektif, namun pelatihan tersebut perlu ditingkatkan lagi karena semua dimensi berada dibawah skor ideal. 
Pemberdayaan menciptakan kondisi untuk motivasi tinggi melalui pengembangan rasa yang kuat self efficacy pribadi, ini berarti berbagi kekuasaan sedemikian rupa bahwa individu belajar untuk percaya pada kemampuan mereka untuk melakukan pekerjaan (Nelson \& Quick, 2012) dengan adanya pemberdayaan karyawan juga menolong karyawan untuk merasa bahwa kontribusi mereka mempunyai arti, bahwa mereka berkompeten dan mereka mempunyai pilihan terhadap apa yang dikerjakannya. Dimensi pemberdayaan menurut Noe et al (2016) yaitu responsibility (tanggung jawab), dan authority (wewenang).

Responsibility (tanggung jawab) yaitu karyawan bertanggung jawab untuk melakukan pekerjaan yang baik dan mengembangkan keterampilan yang terus membuat mereka berharga bagi atasan mereka (Noe et al., 2016). Dengan tanggung jawab muncul pemberdayaan diri dan otoritas diri untuk mengarahkan dan mengambil tindakan yang diperlukan untuk memastikan kesuksesan (Kuhn, 2011). Orang suka mengambil tanggung jawab, karena mereka merasa pekerjaan menjadi lebih berarti (Huq, 2016).

Dalam Autority (wewenang), karyawan harus diberikan wewenang dalam pengambilan keputusan dalam pekerjaannya, kewenangan pengambilan keputusan antara individu, subkelompok, dan tim secara keseluruhan (Noe et al., 2016). Memberikan pegawai lebih banyak wewenang untuk membuat keputusan tentang tugas langsung mereka dapat meningkatkan efektivitas organisasi, dan meningkatkan kepuasan karyawan. Karyawan yang telah diberi wewenang untuk membuat keputusan, merasa pengalaman itu memuaskan dan meningkatkan rasa nilai pribadi mereka sendiri (Lashley, 2012).

Berdasarkan hasil pengolahan data yang dilakukan melalui penyebaran angket pada pegawai PT. Bank Rakyat Indonesia kantor Cabang Kuningan, pelatihan dapat diukur melalui perhitungan rata-rata dimensi dan perhitungan skor keseluruhan. Berikut ini dipaparkan hasil dari rekapitulasi perhitungan skor:

\section{TABEL 4.1}

REKAPITULASI DIMENSI PEMBERDAYAAN

\begin{tabular}{lllll}
\hline No. & Dimensi & $\begin{array}{l}\text { Total } \\
\text { Skor }\end{array}$ & $\begin{array}{l}\text { Skor } \\
\text { Ideal }\end{array}$ & $\%$ \\
\hline Pemberdayaan & & & \\
\hline $1 . \quad$ Responsibility (tanggung jawab) & 4354 & 5250 & $83 \%$ \\
2. Authority (wewenang) & 4092 & 4900 & $84 \%$ \\
\hline \multicolumn{2}{c}{ Total } & $\mathbf{8 4 4 6}$ & $\mathbf{1 0 1 5 0}$ & $\mathbf{8 3 \%}$ \\
\hline
\end{tabular}

Sumber: Hasil Pengolahan Data 2018
Berdasarkan Tabel 4.2 aspek pemberdayaan paling tinggi yaitu terdapat pada dimensi responsibility (tanggung jawab) memperoleh skor sebanyak 4354 atau $83 \%$, sementara dimensi paling rendah yaitu pada authority (wewenang) dan memperoleh skor 4092 atau $84 \%$ Secara keseluruhan variabel pemberdayaan memperoleh skor 8446 , apabila di persentasekan kedalam skor ideal maka diperoleh persentase sebesar $83 \%$, dapat dikatakan menurut (Ali, 2013:184) bahwa hampir seluruh responden menyatakan pemberdayaan pada pegawai PT. Bank Rakyat Indonesia Kantor Cabang Kuningan dalam kategori baik. Sedangkan dilihat dari garis kontinum yang telah dihitung adalah:

\section{GAMBAR 4.2}

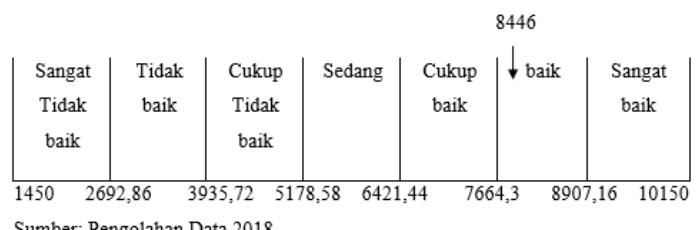

\section{GARIS KONTINUM VARIABEL PEMBERDAYAAN}

Berdasarkan Gambar 4.2 pada nilai kontinum variabel pelatihan yaitu 8446 sesuai dengan data penelitian yaitu termasuk kedalam kategori baik, dengan demikian dapat dikatakan bahwa pegawai diberikan pemberdayaan yang baik dalam perusahaan, akan tetapi pemberdayaan pada perusahaan masih perlu ditingkatkan karena semua dimensi berada di bawah skor ideal.

Berdasarkan hasil penelitian dari angket yang disebar kepada 50 responden diketahui bahwa pemberdayaan pegawai PT. Bank Rakyat Indonesia kantor Cabang Kuningan mencapai skor 8446 dari skor kriterium atau jumlah maksimal perolehan nilai responden terletak pada daerah 7664,3 8907,16 sehingga dapat dikatakan bahwa dalam penelitian ini pemberdayaan pegawai PT. Bank Rakyat Indonesia kantor Cabang Kuningan sudah baik, namun pemberdayaan tersebut perlu ditingkatkan lagi karena semua dimensi berada dibawah skor ideal.

Sumber daya manusia akan merasa puas dalam bekerja apabila aspek pekerjaan dan individunya saling menunjang sehingga dapat dikatakan bahwa kepuasan kerja berkenaan dengan perasaan seseorang tentang menyenangkan atau tidaknya pekerjaan karyawan, kepuasan kerja melibatkan perasaan positif seseorang sehingga individu dapat mengevaluasi pekerjaan yang dikerjakannya (Tom \& Adrian, 2002; Mathis, Jackson, \& Valentine, 2015). Menurut Noe et al 
(2016) terdapat lima dimensi kepuasan kerja, yaitu 1) pay (gaji), 2) the work itself (pekerjaan itu sendiri), 3) supervision (pimpinan), 4) co-workers (rekan kerja), 5) promotions (promosi).

Karyawan umumnya berharap bahwa gaji akan meningkat seiring berjalannya waktu. Karyawan akan puas jika harapannya terpenuhi. (Noe et al., 2016). Pay (gaji) merupakan salah satu yang mempengaruhi kepuasan dalam bekerja karena gaji itu sendiri merupakan apa yang diberikan perusahaan kepada karyawan dan haruslah sesuai dengan apa yang mereka kerjakan (Gibson, 2012).

Karyawan pada suatu organisasi dituntut untuk memiliki tanggung jawab terhadap pekerjaannya. Pekerjaan itu dirancang untuk menjadi sesuatu yang memberi karyawan rasa puas (Noe et al., 2016). The work itself tampaknya menjadi sumber utama kepuasan kerja, terutama karakteristik umpan balik, pekerjaan yang menarik dan menantang, dan pekerjaan yang memberikan status kepada karyawan (Cary Cooper, 2013).

Supervision (pimpinan) menghabiskan sebagian besar waktunya untuk memantau karyawan mereka untuk memastikan tempat kerja aman, kualitas produk terjaga, dan proses kerja menjadi optimal agar karyawan merasakan puas dalam bekerja (Noe et al., 2016). Supervisi yang buruk dapat berakibat absensi dan turn over (Sutrisno, 2017). Supervision harus bekerja untuk menciptakan kondisi yang memfasilitasi upaya pekerja. Supervision memiliki tanggung jawab untuk menjaga diskusi terfokus pada isu-isu terkait pekerjaan dan dalam menentukan situasi kerja. Supervision harus mendengarkan dan membuat saran yang akan membantu karyawan dalam menemukan solusi sendiri (Munson, 2012).

Co workers (rekan kerja) saling membantu untuk mendapatkan beberapa hasil pekerjaan yang memuaskan, rekan kerja dapat memberikan dukungan sosial, yang berarti, simpatik dan peduli. Dukungan sosial sangat meningkatkan kepuasan kerja. Rekan kerja dapat membantu karyawan baru untuk mengetahui tujuan apa yang harus dikejar dan bagaimana mencapainya (Noe et al., 2016).

Promotion (promosi) melibatkan memindahkan karyawan ke posisi yang memiliki tantangan, tanggung jawab, dan wewenang lebih besar daripada pada pekerjaan sebelumnya. Biasanya promosi termasuk kenaikan gaji, karena promosi meningkatkan gaji, status, dan perasaan puas seseorang (Noe et al., 2016). Promosi mengacu pada peningkatan karyawan ke jabatan yang lebih tinggi dengan tanggung jawab yang lebih besar, status yang lebih tinggi, dan gaji yang lebih baik. Ini adalah gerakan ke atas dari seorang karyawan dalam hierarki organisasi, ke pekerjaan lain yang memerintahkan otoritas yang lebih besar, status yang lebih tinggi, dan kondisi kerja yang lebih baik.(Sharma, 2016).

Berdasarkan hasil pengolahan data yang dilakukan melalui penyebaran angket pada pegawai PT. Bank Rakyat Indonesia kantor Cabang Kuningan, pelatihan dapat diukur melalui perhitungan rata-rata dimensi dan perhitungan skor keseluruhan. Berikut ini dipaparkan hasil dari rekapitulasi perhitungan skor:

\section{TABEL 4.3}

TABEL REKAPITULASI DIMENSI KEPUASAN KERJA

\begin{tabular}{llccc}
\hline No. & \multicolumn{1}{c}{ Dimensi } & $\begin{array}{c}\text { Total } \\
\text { Skor }\end{array}$ & $\begin{array}{c}\text { Skor } \\
\text { Ideal }\end{array}$ & \% \\
\hline Pemberdayaan & & & \\
\hline 1. Pay (gaji) & 3928 & 4900 & $80 \%$ \\
2. The Work Itself (pekerjaan itu sendiri) & 4394 & 5250 & $84 \%$ \\
3. Supervision (pimpinan) & 3946 & 4900 & $81 \%$ \\
4. Coworkers (rekan kerja) & 4492 & 5250 & $86 \%$ \\
5. Promotions (promosi) & 2468 & 3150 & $78 \%$ \\
\hline \multicolumn{1}{c}{ Total } & $\mathbf{1 9 2 2 8}$ & $\mathbf{2 3 4 5 0}$ & $\mathbf{8 2 \%}$ \\
\hline Sumber: Hasil Pengolahan Data 2018 & & &
\end{tabular}

Berdasarkan Tabel 4.3 aspek kepuasan kerja paling tinggi yaitu terdapat pada dimensi co workers (rekan kerja) memperoleh skor sebanyak 4492 atau $86 \%$, sementara dimensi paling rendah yaitu pada promotions (promosi) memperoleh skor 2468 atau $78 \%$ Secara keseluruhan variabel kepuasan kerja memperoleh skor 19228, apabila di persentasekan kedalam skor ideal maka diperoleh persentase sebesar $82 \%$, dapat dikatakan menurut Moch Ali (2013:184) bahwa hampir seluruh responden menyatakan kepuasan kerja pada pegawai PT. Bank Rakyat Indonesia Kantor Cabang Kuningan dalam kategori baik (Ali, 2013) Sedangkan dilihat dari garis kontinum yang telah dihitung adalah:

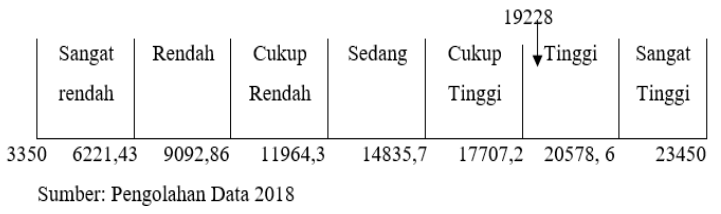

GAMBAR 4.3

GARIS KONTINUM VARIABEL KEPUASAN KERJA

Berdasarkan Gambar 4.3 pada nilai kontinum variabel kepuasan kerja yaitu 19228 sesuai dengan data penelitian yaitu termasuk kedalam kategori puas, dengan demikian dapat dikatakan bahwa pegawai mengikuti kepuasan kerja yang baik dijalankan pada perusahaan, akan tetapi 
kepuasan kerja pada perusahaan masih perlu ditingkatkan karena semua dimensi berada di bawah skor ideal.

Berdasarkan hasil penelitian dari angket yang disebar kepada 50 responden diketahui bahwa kepuasan kerja pegawai PT. Bank Rakyat Indonesia kantor Cabang Kuningan mencapai skor 8446 dari skor kriterium atau jumlah maksimal perolehan nilai responden terletak pada daerah 17707,2 20578,6 sehingga dapat dikatakan bahwa dalam penelitian ini kepuasan kerja pegawai PT. Bank Rakyat Indonesia kantor Cabang Kuningan sudah baik, namun kepuasan kerja tersebut perlu ditingkatkan lagi karena semua dimensi berada dibawah skor ideal.

Berdasarkan penelitian diatas menyatakan bahwa semakin tinggi pelatihan dan pemberdayaan secara bersama-sama, maka semakin tinggi pula kepuasan PT. Bank Rakyat Indonesia kantor Cabang Kuningan tersampaikan.. Hal ini menunjukkan bahwa semakin tinggi pelatihan semakin tinggi juga kepuasan kerja PT. Bank Rakyat Indonesia kantor Cabang Kuningan yang tersampaikan. Selain itu, pemberdayaan berpengaruh kepuasan kerja. Hal ini menunjukkan bahwa semakin baik pemberdayaan semakin tinggi kepuasan kerja PT. Bank Rakyat Indonesia kantor Cabang Kuningan yang tersampaikan.

\section{KESIMPULAN DAN REKOMENDASI}

Berdasarkan hasil penelitian yang telah dilakukan menggunakan analisis deskriptif . Dapat diambil kesimpulan yaitu bahwa pelatihan berada pada kategori baik terlihat dari pelatihan meningkatkan kualitas pegawai dalam memasarkan produk perusahaan. Pemberdayaan berada pada kategori baik terlihat dari pegawai menyelesaikan pekerjaan dengan tepat waktu. Kepuasan kerja berada pada kategori tinggi terlihat dari pegawai memiliki rekan kerja yang menyenangkan.

Adanya penelitian ini diharapkan dapat membantu peneliti berikutnya dalam melakukan penelitian mengenai pelatihan, pemberdayaan dan kepuasan kerja dengan menggunkan indikator yang berbeda dari sumber teori yang lebih beragam, dan terhadap objek yang berbeda, karena masih banyaknya keterbatasan dalam penelitian ini, khususnya yang berkaitan dengan metode penelitian dan teknik pengumpulan data.

\section{DAFTAR PUSTAKA}

Agbozo, G. K., Owusu, I. S., Hoedoafia, M. A., \& Atakorah, Y. B. (2017). The Effect of Work
Environment on Job Satisfaction: Evidence from the Banking Sector in Ghana. Journal of Human Resource Management, 5(1), 12-18. https://doi.org/10.11648/j.jhrm.20170501.12

Al Adresi, A., \& Darun, M. R. (2017). Investigating mediating effect of perceived organizational support between SHRM practices and employee trust. International Journal of Engineering Business Management, 9, 1-10. https://doi.org/10.1177/1847979017701131

Alexandris, K. (2013). Performance Measurement and Leisure Management. USA: Routledge.

Ali, M. (2013). Penelitian Kependidikan Prosedur dan Strategi. Bandung: CV Angkasa.

Ampauleng. (2016). Analisis Pelatihan Dan Pemberdayaan Terhadap Kepuasan Kerja Karyawan Di Perusahaan PT. Sumber Cipta Multiniaga Cabang Makassar, (Xix), 1-20.

Arulrajah A. (2017). Human Resource Management Practices and Innovation: a Review of Literature. 11th International Conference on Business Management - 2014, 18(2009), 5567. https://doi.org/10.2139/ssrn.2149464

Bagus, I., Dharmanegara, A., Sitiari, N. W., \& Adelina, M. E. (2016). The impact of organizational commitment, motivation and job satisfaction on civil servant job performance in State Plantation Denpasar. Journal of Business and Management, 18(2), 41-50. https://doi.org/10.9790/487X18224150

Batarliene, N., Čižiuniene, K., Vaičiute, K., Šapalaite, I., \& Jarašuniene, A. (2017). The Impact of Human Resource Management on the Competitiveness of Transport Companies. Procedia Engineering, 187, 110-116. https://doi.org/10.1016/j.proeng.2017.04.356

Cary Cooper, Ian R. )2013(. Organizational and Work Psychology: Topics in Applied Psychology. New York: Routledge.

Chan, K. (2014). International Conference on Humanity and Social Science. USA: Destech Publication inc.

Charles Leatherbarrow, J. F. (2014). Introduction to Human Resource Management: A Guide to HR in Practice. London: CIPD.

Chien, J. (2015). The Impact of Change Management on Employee Satisfaction and Engagement, 9(5), 1680-1685.

Dail L, F. (2002). Taking the Measure of Work: A Guide to Validated Scales for Organizational Research and Diagnosis. USA: SAGE Publications.

Delery, J. E., \& Roumpi, D. (2017). Strategic human resource management, human capital 
and competitive advantage: is the field going in circles? Human Resource Management Journal, 27(1), 1-21.

Eliphas, R. (2017). The influence of performance appraisal practices on employee productivity : A case of Muheza District , 5(4), 45-59.

Garry, D. (2013). Human Resource Management. New Jersey: Pearson Prentice Hall.

Gibson. (2012). Organizations: Behavior, Structure, Process. New York: Mc. Graw Hill.

Hidayat, R. (2013). Pengaruh Kepemimpinan terhadap Komunikasi, Kepuasan Kerja, dan Komitmen Organisasi pada Industri Perbankan, 17(1), 19-32.

Huq, R. A. (2016). The Psychology of Employee Empowerment: Concepts, Critical Themes and a Framework for Implementation. USA: Routledge.

Ina Ehnert, Wes Harry, K. J. Z. (2013). Sustainability and Human Resource Management: Developing Sustainable Business Organizations. New York and london: Springer.

Jain, Ruchi, Kaur, S. (2014). Impact of Work Environment on Job Satisfaction. International Journal of Scientific and Research Publication, 4(1), 1-8. https://doi.org/ISSN 2250-3153

Jayanthi, F. R. (2014). Analisis Pengaruh Kepuasan Kerja dan Kualitas Pelayanan Terhadap Kepuasan Nasabah Bank Syariah (Studi di Bank Muamalat Cabang Malang).

Jean M. Phillips, S. M. G. (2013). Human Resource Management. New Jersey, USA: Cengage Learning.

Johnson, M., \& Umoh, G. I. (2016). Training and Employee Work Attitudes of Selected Manufacturing Firms in Port, 3(3), 101-112.

Keyes, J. (2016). Implementing the IT Balanced Scorecard: Aligning IT with Corporate Strategy. New York: Taylor \& Francis.

Khanka, S. S. (2007). Human Resource Management. New Delhi: S. Chand Publishing.

Kuhn, R. E. (2011). Self-Empowerment 101. Orcas Island: The Paradigm Shifts.

Lashley, C. (2012). Empowerment: HR Strategies for Service Excellence. New York: Routledge.

Lesley Walls, Matthew Revie, T. B. (2017). Risk, Reliability and Safety: Innovating Theory and Practice. London and New York: CRC Press.

Locke, E. . (1976). The nature and causes of job satisfaction. In M.D. Dunnette. Chicago: Rand McNally.
M. Ronald Buckley, Anthony R. Wheeler, J. R. B. H. (2017). Research in Personnel and Human Resources Management. UK: Emerald Publishing.

Mahmood, S., \& Ur Rehman, A. (2016). Impact of Effective Vision Attributes on Employee Satisfaction. International Journal of Economics \& Management Sciences, 05(02). https://doi.org/10.4172/2162-6359.1000315

Maimako, L. B., \& Bambale, A. J. (2016). Human Resource Management Practices and Employee Job Satisfaction in Kano State owned Universities: A Conceptual Model, 7(2), 1-16.

Maitland, L. L. (2014). 5 Steps to a 5 AP Psychology. New York: McGraw Hill Professional.

Marta, Z.-K. (2014). Human Resources - Attracting the Best Candidate for Your Company. GRIN Verlag.

Masharyono, Syamsul. H. Senen, S. (2017). Employee Performance Assessment System Design Based on Competence. Innovation of Vacational Technology Education, 2(8), 6870.

Masharyono, Sumiyati, Purnama, R., \& Pratama, K. F. (2016). The Effect of Social Work Environment on Employee Productivity in Manufacturing Company in Indonesia. Atlantis Press, 15, 574-575.

Mathis, R. L., Jackson, John H. \&,Valentine ,Sean R. (2015). Human Resource Management: Essential Perspectives. USA: Cengage Learning.

Maulana, R., \& Anindita, R. (2017). Role of Organizational Commitment towards Relationship between Job Satisfaction and Turnover Intentions A Case in Hospitality Industry, 19(10), 33-39.

Michael, S. (2009). Quality Concepts for the Process Industry. USA: Cengage Learning.

Mullins, L. J. (2005). Management and Organisational Behaviour (7th ed.). england: Prentice Hall.

Munson, C. (2012). Handbook of Clinical Social Work Supervision. Maryland: The Haworth Press.

Navarro, J. G. C. (2015). Proceedings of The 7th European Converence on Intellectual Capital. UK: Academic Conferences Limited.

Nelson, D., \& Quick, J. (2012). ORGB 3, Student Edition. USA: South Western.

Neog, B. B. (2014). Factors Influencing Employee's Job Satisfaction: An Empirical Study among Employees of Automobile 
Service Workshops in Assam. The Standard International Journals (TheSIJ Transactions on Industrial, Financial \& Business Management (IFBM), 2(7), 305-316.

NM, N., KM, F., \& SM, A. (2017). The Role and Impact of Business Communication on Employee Performances and Job Satisfactions: A Case Study on Karmasangsthan Bank Limited, Bangladesh, 7(1), 1-8. https://doi.org/10.4172/22235833.1000293

Noe, R. A., Hollenbeck, J. R., Gerhart, B., \& Wright, P. M. (2016). Fundamentals of Human Resource Management.

Nuryanti, B. L., \& Rahmawati, R. (2016). The Influence of Situational Leadership and Work Environment towards Employees , Performance, 15, 540-543.

Nuryanti, L., \& Afriyady, M. A. (2016). Gambaran disiplin kerja dan kompensasi berpengaruh pada kepuasan kerja karyawan pdam tirta berkah kabupaten pandeglang, 1(2), 75-80.

Olagunju, M. M. (2014a). Effect of Training on Employees' Performance in Nigerian Banking Industry. USA: Author House.

Olagunju, M. M. (2014b). Effect of Training on Employees Performance in Nigerian Banking Industry. USA: Author House.

Osama, S., Haseeb, B., Waseem, R. M., Ayaz, M., \& Ijaz, M. (2016). Impact of Training and Development of Employees on Employee Performance through Job Satisfaction: A Study of Telecom Sector of Pakistan, 7(1), 29-46. https://doi.org/10.5296/bms.v7i1.9024

Rama, T. A. (2017). Organizational Citizenship Behavior ( Pada Pegawai Kantor Perwakilan Bank Indonesia, 5(1), 125-133.

Raziq, A., \& Maulabakhsh, R. (2015). Impact of Working Environment on Job Satisfaction. Procedia Economics and Finance, 23(October 2014), 717-725.

Risher, H., \& Wilder, W. (2016). It's Time for High-Performance Government: Winning Strategies to Engage and Energize the Public Sector Workforce. london: Rowman \& Littlefield.

Robert L, M., \& Jackson, J. H. (2010). Human Resource Management (13th ed.). SouthWestern: Cengage Learning.

Sari, I. P. (2017). Effect of Learning Culture, Empowerment, and Cyber Skill Competency on self-engagement Employees, 1(2), 1-9.

Sharma, F. C. (2016). Human Resource Management. Agra: SBPD Publications.

Sumiyati, Masharyono, Purnama, R., \& Pratama, K.
F. (2016). The Influence of Social Work Environment on Employee Productivity in Manufacturing in Indonesia. Atlantis Press, 15, 649-652.

Sutrisno, E. (2017). Manajemen Sumber Daya Manusia. Jakarta: Kencana Prenada Media.

Tetik, N. (2016). The Effects of Psychological Empowerment on Job Satisfaction and Job Performance of Tourist Guides, 6(2), 221239. https://doi.org/10.6007/IJARBSS/v6i2/2026

Tom, R., \& Adrian, W. (2002). The Informed Student Guide to Human Resource Management. North Yorkshire: Thomson Learning.

Tran, L., \& Thao, T. (2015). Factors Affecting Employee Performance - Evidence From Petrovietnam Engineering Consultancy J.S.C.

Tsounis, N., \& Vlachvei, A. (2017). Advances in Applied Economic Research: Proceedings of the 2016 International Conference on Applied Economics (ICOAE). Switzerland: Springer.

Uddin, M. J., Chowdhury, M., \& Yasmin, M. (2016). Job Satisfaction of the Employees of the General Insurance Companies in Bangladesh, 5(1), 7-18.

V.S.P. Rao, V. H. K. (2009). Management: Text and Cases. New Delhi: Excel Books.

Vallabhaneni, S. R. (2017). Wiley CIAexcel Exam Review 2017: Part 3, Internal Audit Knowledge Elements. New Jersey, USA: John Wiley \& Sons.

Veithzal, R., \& Ella Jauvani, S. (2014). Manajemen Sumber Daya Manusia untuk Perusahaan: Dari Teori ke Praktik (kedua). Jakarta: Rajawali Pers.

Vi, S. (2017). Role of Human Resource Manage ment in Micro, Small and Medium Enterprises ( MSME ) in India, 7(1), 26-34.

Vriti, V. (2015). Organizational Stress Really Matters in Career Satisfaction? Germany: Anchor Academic Publishing.

Waqas, A., Umair, B., Sattar, M. F., Abdullah, H. M., Hussain, I., Anjum, W., ... Arshad, R. (2014). Factors Influencing Job Satisfaction and Its Impact on Job Loyalty. International Journal of Learning \& Development, 4(2), 141-161. https://doi.org/10.5296/ijld.v4i2.6095

Wilton, N. (2016). An Introduction to Human Resource Management. london: SAGE edge.

Zafeiti, S. M. B., \& Noor, A. M. (2017). The Influence of Organizational Commitment on Omani Public Employees , Work Performance. International Review of 
Journal of Business Management Education | Volume 3, Number 3, December 2018, page. 1-13

Management and Marketing, 7(2), 151-160.

Zhang, Y. (2016). A Review of Employee Turnover Influence Factor and Countermeasure, (June), 85-91.

Zu'Tubi, H. A. A.-, \& Alkharabsheh, S. A. (2016). Investigating the Impact of Training Management Strategy on Core Competencies. International Journal of Academic Research in Business and Social Sciences, 6(5), 437445. https://doi.org/10.6007/IJARBSS/v6$\mathrm{i} 5 / 2159$

www.salaryexplorer.com diakses tanggal 03/09/2017 pukul 17.29

www.jobplanet.com diakses tanggal 18/09/2017 pukul 15.43 